Published by LPMP Imperium

Journal homepage: https:/ / ejournal.imperiuminstitute.org/ index.php/JMSAB

\section{Pemanfaatan Data Pemasaran Digital Dalam Penentuan Lokasi Geografis Terbaik Untuk Penempatan Iklan Produk}

\author{
Tinton Ramadhan*, Ika Suhartanti Darmo \\ Manajemen, Fakultas Bisnis, Institut Teknologi dan Bisnis Kalbis
}

\begin{abstract}
This study aims to find out how to use digital marketing data from Facebook ads's marketing campaign in determining the best geographical location for product ad placement. The research method used is an advertising experiment by testing a product advertising design that produces digital marketing data. The data is then analyzed with sales data in the advertising period to get the best-performing geographic location seen from the regions that generate the most sales. The result is by focusing ad placement on the regions that generate the most sales in previous experiments, the percentage of advertising expenses compared to revenue generated has decreased from $84 \%$ when arranged placement across Indonesia to $47 \%$ at the provincial level with the most sales and decreased again to $31 \%$ when it is focused at the city level with the most sales
\end{abstract}

\begin{abstract}
Abstrak
Penelitian ini bertujuan untuk mengetahui cara menggunakan data pemasaran digital yang diperoleh dari kampanye pemasaran iklan menggunakan "facebook ads" dalam menentukan lokasi geografis terbaik untuk penempatan iklan produk. Metode penelitian yang digunakan adalah eksperimen iklan dengan cara uji coba rancangan iklan produk yang menghasilkan data pemasaran digital. Data tersebut kemudian dianalisa dengan data penjualan pada periode iklan untuk mendapatkan lokasi geografis dengan performa terbaik yang dilihat dari wilayah yang menghasilkan penjualan terbanyak. Hasilnya dengan memfokuskan penempatan iklan pada wilayah yang menghasilkan penjualan terbanyak pada eksprerimen sebelumnya, persentase beban iklan dibandingkan pendapatan yang dihasilkan berhasil menurun dari $84 \%$ saat diatur penempatan-nya di seluruh Indonesia menjadi $47 \%$ di tingkat wilayah provinsi dengan penjualan terbanyak dan menurun lagi menjadi $31 \%$ saat di fokuskan di tingkat kota dengan penjualan terbanyak.
\end{abstract}

*Email korespondensi: tinton.ramadhan@kalbis.ac.id

Pedoman Sitasi: Ramadhan, T \& Darmo, I.S. (2020). Pemanfaatan Data Pemasaran Digital Dalam Penentuan Lokasi Geografis Terbaik Untuk Penempatan Iklan Produk. Jurnal Manajemen Strategi Dan Aplikasi Bisnis, $3(1), 51$ - 64 .

\section{JMSAB}

\section{1}

Paper type

Research paper

Keywords: : facebook ads, geographical location, ad placement, marketing data.

Received: 28 Feb 2020

Revised: 24 Mei 2020

Accepted: 1 Jun 2020

Online: 6 Jun 2020

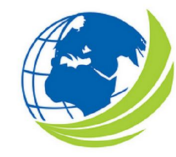

Jurnal Manajemen Strategi dan Aplikasi Bisnis, Vol 3, No.1, Januari-Juni 2020, pp. 51-64

eISSN 2655-237X 


\section{PENDAHULUAN}

Perkembangan pemasaran digital di Indonesia terus mengalami peningkatan yang cukup menjanjikan dari waktu ke waktu. Penetrasi internet dan media sosial yang terus menanjak naik di antara lebih dari 260 juta penduduk. Indonesia kini memperlihatkan potensinya sebagai target pasar yang cukup menjanjikan di Asia Tenggara, terutama dalam urusan pemasaran produk. Layanan content marketplace, GetCraft merilis sebuah laporan terkait perkembangan praktik pemasaran di Indonesia. (Maulana, 2017:1). Hampir delapan puluh juta orang Indonesia merupakan pengguna aktif media sosial. Angka tersebut tentunya menjadi sasaran potensial bagi kalangan pemasar. Di belakangnya menyusul iklan media sosial. GetCraft mencatat, di tahun 2016 para pengiklan rata-rata memperoleh keuntungan sebesar Rp 1,9 miliar per tahun untuk keperluan kampanye pemasaran digital. Menurut GetCraft, perolehan traksi yang jelas dan terukur membuat model pemasaran ini lebih efektif dari segi ROI (return of investment) dibandingkan pemasaran lainnya (Maulana, 2017:1).

Salah satu pemimpin pasar sosial media yang menyediakan platformnya sebagai media pemasaran berbayar adalah Facebook. Menurut data, hampir seperempat populasi di dunia adalah pengguna Facebook-tepatnya 22,9 persen. Dengan jumlah pengguna aktif bulanan yang begitu besar, pada 2015 Facebo ok berhasil meraup uang sebanyak \$17,1 miliar. Tahun lalu, pendapatannya naik lagi hingga mencapai $\$ 26,9$ miliar. Sebagian besar pendapatan tersebut dihasilkan melalui iklan yang mereka tawarkan (Zaenudin, 2017:1). Setidaknya, ada dua pendekatan bagi para publisher atau siapa saja yang hendak mempromosikan konten atau barang dagangan mereka di Facebook. Cara terbaik dan termudah adalah melalui layanan iklan resmi di Facebook. Dengan membayar sejumlah biaya, Facebook akan memberikan tempat di Newsfeed dan dapat memberikan estimasi berapa orang yang akan melihat iklan tersebut. Salah satu alasan beriklan di platform ini, sebagaimana dikutip Forbes, adalah Facebook mengirimkan trafik lebih besar bagi publisher dibandingkan Google.Fortune, yang mempublikasikan hasil penelitian layanan analisis lalu-lintas website dari Parse.ly, menyebut Facebook mendatangkan hingga 43 persen trafik, sedangkan Google hanya 38 persen saja. Parse.ly menggunakan data dari klien-kliennya yang berjumlah lebih dari 400 penerbit (Zaenudin, 2017:1).

Hal menarik lain dari beriklan di Facebook adalah para pengiklan bisa mendapatkan data dari hasil kegiatan pemasaran tentang kinerja iklan yang dijalankan di Pengelola Iklan. Data ini mencakup: jumlah orang yang melihat iklan, lokasi orang yang melihat iklan, jumlah orang yang mengklik iklan dan jumlah yang dibelanjakan pada iklan. Data-data tersebut dapat dianalisis untuk meningkatkan kinerja iklan. Menurut pendapat Kasali sebagaimana dikutip oleh Jushermi (2013:1) dalam ilmu pemasaran, sebelum melakukan macam-macam kampanye kemasyarakatan atau pendekatan pemasaran lainnya, pasar yang dibidik harus jelas lebih dahulu. Lebih dari $60 \%$ kegagalan bisnis disebabkan oleh gagalnya pengusaha mendefinisikan pasar yang dituju. Sehingga menurut Kotler dan Armstrong dalam Jushermi (2013:2-3), semakin banyak perusahaan menyadari masa mass marketing telah berakhir. Perusahaan semakin menyadari bahwa pasar terdiri dari banyak pembeli, dan para pembeli berbeda dalam hal keinginan, daya beli, lokasi dan perilaku belanja. Melalui segmentasi, perusahaan membagi pasar yang besar dan heterogen menjadi segmensegmen yang lebih kecil yang dapat dijangkau secara efisien dan efektif dengan produk dan layanan yang unik sesuai dengan kebutuhan pasar. Menurut Kotler (2018), variabel utama yang dipergunakan dalam mensegmentasi pasar konsumen adalah sebagai berikut: segmentasi geografis, segmentasi demografis, segmentasi psikografis, segmentasi perilaku.

Studi ini dilakukan berdasarkan beberapa hal: pertama, studi mengenai segmentasi pasar dalam kaitannya dengan penempatan iklan masih relatif jarang diteliti di Indonesia. Beberapa studi seperti Van den Broeck dan Walrave (2020); Gordon et al. (2019); dan Semerádová dan Weinlich (2019) dilakukan di Amerika dan Eropa kemungkinan memiliki perbedaan mendasar terkait dengan segmentasi pasar di sana dan perilaku konsumennya yang berbeda. Kedua, studi lain seperti Giroux, Pons, \& Maltese (2017) menggunakan brand personality untuk memprediksi efektivitas promosi, 
Jurnal Manajemen Strategi dan Aplikasi Bisnis, 3(1), 51 - 64

Tinton Ramadhan \& Ika Suhartanti Darmo. Data pemasaran digitial, lokasi geografis

Luo (2017) menggunakan pendekatan demografi untuk memperdiksi perilaku pembelian, Studi lainnya, Nguyen et al. (2019) menjelaskan bahwa berbagai literatur masih menunjukkan temuan yang bertentangan mengenai hubungan antara demografi dan konsumsi berkelanjutan, dan nilai demografi untuk segmentasi konsumen yang berkelanjutan dan kampanye perubahan perilaku yang ditargetkan telah diperdebatkan oleh beberapa peneliti. Berdasarkan hal itu peneliti ingin meneliti lebih lanjut mengenai pemanfaatan data pemasaran digital. Hasil penelitian nantinya diharapkan bisa menjadi model dalam perancangan iklan di media digital yang tepat sasaran.

\section{KAJIAN PUSTAKA}

Pemasaran online menurut Belch dan Belch sebagaimana dikutip oleh Ekawati (2012:2) adalah pemasaran dengan menggunakan fasilitas koneksi internet dimana perusahaan melakukan upayaupaya untuk memasarkan produk dan pelayanan serta membangun hubungan dengan pelanggan melalui internet. Alat-alat komunikasi pemasaran salah satunya adalah internet marketing. Pada saat ini internet sudah menjadi kebutuhan sehari-hari oleh masyarakat untuk mendapatkan informasi. Maka dengan menggunakan internet marketing perusahaan dapat menjangkau konsumen lebih mudah dan cepat.

Prisgunanto menyatakan sebagaimana dikutip oleh Ekawati (2012:3) Internet dapat menjadi suatu prospek yang menarik pemasar untuk menentukan aplikasi komunikasi pemasaran dan riset pemasaran aspek yang cocok dengan produk yang ditawarkan. Hermawan sebagaimana dikutip oleh Ekawati (2012:3) mengungkapkan bahwa Pemasaran Internet (Internet Marketing) juga disebut sebagai pemasaran web marketing, online marketing atau e-marketing atau e-commerce adalah pemasaran dari produk atau jasa melalui internet. Pemasaran internet menuntut adanya penguasaan aspek kreatif dan aspek teknis internet secara bersama-sama termasuk desain, pengembangan, periklanan, dan penjualan.

Jaringan sosial telah menjadi kekuatan penting baik dalam bisnis ke konsumen (B2C) dan pemasaran bisnis ke bisnis (B2B). Salah satunya Facebook, Twitter, Blackberry Messanger, dan lainlain. Jaringan yang berbeda menawarkan manfaat yang berbeda untuk perusahaan (Kotler \& Keller, 2012). Social networking digunakan untuk mengiklankan produk dan jasa perusahaan sehingga menarik perhatian konsumen. Dalam situs jejaring sosial memiliki kemampuan untuk menciptakan hubungan yang baik dengan konsumen sehingga hubungan yang baik dapat terciptanya pengulangan konsumen terhadap produk. Serta situs jejaring sosial memiliki kemampuannya untuk membentuk jejaring sosial dan pemasaran viral (Chailom \& Kaiwinit, 2015). Media sosial adalah alat digital yang memungkinkan percakapan diantara prospek atau konsumen dengan pelaku bisnis. Situs sosial media yang saat ini sering digunakan untuk melakukan aktifitas pemasaran online diantara Facebook, Twitter, instagram, pinterest dan youtube (Turner, 2011).

\section{Facebook Ads}

Yuhefizar mengungkapkan sebagaimana dikutip oleh Ekawati (2012: 4) Facebook didefinisikan sebagai salah satu jenis website yang memiliki fasilitas bagi penggunanya untuk membangun jejaring pertemanan melalui internet. Selain membangun hubungan, Facebook dapat saling berbagi informasi, foto, video, dan informasi produk bisnis. Dewasa ini Facebook digunakan oleh banyak perusahaan dalam kegiatan promosi baik dilakukan secara gratis maupun secara berbayar. Mereka memanfaatkan fitur promosi pada Facebook seperti wall, foto, video, group, catatan, event, tautan, fan pages dan iklan berbayar di Facebook.

Facebook Ads merupakan sebuah fitur yang disediakan oleh Facebook untuk para pebisnis online untuk menawarkan atau mengiklankan jualan mereka. Juga digunakan oleh brand, komunitas, public figure, partai politik, panitia seminar, konser musik serta siapapun yang ingin mengenalkan produk atau jasanya melalui Facebook Ads. Salah satu kelebihan beriklan di Facebook ads adalah pada detailnya target iklan yang disedika. Pengiklan cukup memiliki halaman di Facebook ditambah 
dengan aanggaran iklan sebesar Rp. 50.000 sehari sudah cukup untuk meningkatkan pemirsa, meningkatkan partisipasi pengguna dan pilihan lainnya. Dalam hal ini pengiklan dapat memilih opsi seperti: Page Post Engagement, Page Likes, Clicks to Website, Website Conversion, Apps atau Events. Selanjutnya bisa memilih target market yang benar, seperti lokasi, umur, jenis kelamin, minat, bahasa, dan masih banyak kategori lainnya (Ekawati, 2012:4).

\section{METODE}

\section{Desain dan Prosedur Penelitian}

Prosedur dalam penelitian ini akan menjelaskan cara menjalankan kampanye iklan sebagai cara pengambilan data dengan menggunakan eksperimen.

\section{Kampanye Iklan 1}

Dalam kampanye iklan yang pertama, setiap orang di Indonesia menjadi target dari iklan yang ditayangkan. Segmen geografis konsumen yang ditargetkan pada kampanye iklan yang pertama dibuat secara luas untuk bisa menjangkau sebanyak mungkin lokasi yang menurut algoritma facebook memiliki kecenderungan untuk tertarik dengan produk yang ditampilkan. Kampanye iklan akan dilakukan selama sebulan penuh untuk mendapatkan data yang cukup memadai untuk dilakukan analisis.

\section{Kampanye Iklan 2}

Dalam kampanye iklan yang kedua, data dari penanyangan iklan pertama dianalisis dengan memperhatikan hasil konversi penjualan dari iklan pertama berdasarkan lokasi geografis konsumen. Lokasi terbaik di kampanye iklan pertama, yang terlihat dari hasil penjualan menjadi segmen geografis yang ditargetkan untuk menayangkan iklan, artinya ukuran pasar di kampanye iklan yang kedua diperkecil. Kampanye iklan kedua juga akan dilakukan selama sebulan penuh untuk mendapatkan data yang cukup memadai dan perlakuan yang sama untuk dilakukan analisis dan perbandingan dengan kampanye iklan pertama.

Kampanye Iklan 3

Dalam kampanye iklan yang ketiga, data dari penanyangan iklan kedua dianalisis dengan memperhatikan konversi hasil penjualan dari kampanye iklan berdasarkan lokasi geografis konsumen. Lokasi terbaik akan menjadi fokus utama penanyangan iklan, artinya ukuran pasar kembali dipersempit, hanya di lokasi dengan jumlah penjualan terbanyak. Kampanye iklan ketiga juga akan dilakukan selama sebulan penuh untuk mendapatkan data yang cukup memadai dan perlakuan yang sama untuk dilakukan analisis dan perbandingan denan kampanya iklan kedua dan pertama.

\section{Partisipan}

Partisipan dalam studi ini bervariasi sesuai dengan kampanye periklanan yang akan dijalankan. Di semua kampanye periklanan profil dan materi partisipan iklan akan sama tanpa ada perubahan. Perubahan akan dilakukan pada lokasi konsumen yang ditarget berdasarkan hasil dari kampanye iklan sebelumnya. Hanya orang-orang yang tinggal di Indonesia, berjenis kelamin wanita dan berumur 25-35 tahun yang menjadi target eksperimen iklan ini, sesuai dengan target produk yang akan ditayangkan. Sementara materi iklan akan berupa foto, teks dan link ke website toko.

Eksprerimen iklan dalam penelitian ini dilakukan dengan kolaborasi dari pemilik usaha rintisan usaha. Peneliti mendapatkan akses ke materi periklanan salah satu produk dari usaha agar dapat melakukan ekperimen periklanan ini. Pemilik dari usaha yang menentukan materi iklan sebelum ditayangkan. Iklan dibuat dengan menggunakan Ads Manager di dalam Facebook Business Manager. Kampanye akan berlangsung Desember-Februari untuk 3 (tiga) periode kampanye yang 
Jurnal Manajemen Strategi dan Aplikasi Bisnis, 3(1), 51 - 64

Tinton Ramadhan \& Ika Suhartanti Darmo. Data pemasaran digitial, lokasi geografis

berjalan masing-masing 1 (satu) bulan.

\section{Pengukuran Variabel}

Variabel kontrol

Sebagai kontrol agar hubungan antara variabel bebas dan terikat bisa konstan, maka dibutuhkan variabel kontrol dalam penelitian ini. Variabel kontrol dalam penelitian ini adalah pengaturan yang sama untuk penentuan iklan di setiap kampanye. Pengaturan tersebut adalah sebagai berikut:

Di setiap kampanye iklan, pengaturan akan diatur dengan cara yang sama, yaitu:

- Tujuan lalu lintas (traffic) ke laman tujuan (landing page),

- Pengoptimalan anggaran kampanye dibuat aktif.

- Strategi tawaran kampanye menggunakan strategi biaya terendah.

- Iklan akan dijalankan sepanjang waktu selama anggaran tersedia.

- Anggaran yang disediakan berada dalam kisaran Rp 1.150.000 selama periode satu bulan

- Jenis pengiriman standar dimana anggaran dipakai selama periode yang ditetapkan (1 bulan) dan tidak ada percepatan.

Pengaturan diatas diterapkan dengan sama ke semua kampanye iklan, yaitu:

- Lalu lintas kunjungan di optimalkan ke situs web

- Materi iklan tidak dinamis (agar tidak berubah)

- Tidak mengaktifkan program promo

- Pemirsa yang dituju adalah perempuan berusia 25-35 tahun

- Penempatan iklan dilakukan secara manual, dengan menggunakan pengaturan pada semua perangkat.

- Iklan dioptimalkan untuk pemirsa memencet tombol tautan.

- Dimulai untuk periode satu bulan yang dimulai dari bulan desember untuk kampanye iklan pertama dan bulan februari untuk kampanye iklan terakhir atau ketiga.

Semua kampanye iklan juga akan menggunakan materi iklan, produk, teks dan gambar yang sama sebagai berikut:

Variabel Bebas

Dalam penelitian ini yang menjadi variabel bebas adalah lokasi geografis konsumen. Pengaturan-nya akan dimulai di geografis yang lebih luas, yaitu Indonesia dan kemudian mengerucut di kampanye iklan kedua dan ketiga. Penentuan lokasi geografis pada kampanye kedua dan ketiga ditetapkan setelah dilakukan analisis atas data pemasaran digital dan data penjualan yang terjadi pada periode tersebut.

Variabel Terikat

Dalam penelitian ini yang menjadi variabel terikat adalah nilai persentase yang dihasilkan dari perbandingan antara biaya kampanye iklan terhadap hasil penjualan produk dari iklan tersebut. Turun-nya nilai persentase akan menunjukkan bahwa iklan pada periode tersebut memiliki performa lebih baik dari iklan pada periode sebelumnya yang dipengaruhi oleh variabel bebas berupa lokasi geografis calon konsumen.

\section{Teknik Analisis}

Pengumpulan data dalam penelitian ini diperoleh dengan melakukan penanyangan iklan di facebook ads untuk mendapatkan data-data yang diinginkan khususnya lokasi konsumen potensial dengan memanfaatkan algoritma facebook. Untuk dapat melakukan eksperiman iklan, Facebook Business usaha digunakan untuk membuat dan mendapatkan data dari periklanan yang dibuat lewat Ads Manager.Analisis data dilakukansecara kuantitatif untuk menganalisis data-data berupa angka yang 
didapatkan dari penanyangan iklan. Penelitian ini akan mengukur seberapa banyak jumlah uang yang dihabiskan di setiap kampanye iklan yang kemudian dibandingkan dengan hasil penjualan-nya. Peneliti juga menanyakan pemilik dari usaha untuk mendapatkan data penjualan produk terkait selama kampanye iklan berlangsung untuk dianalisa dan diperbandingkan. Selanjutnya peneliti akan menyajikan data dalam bentuk uraian singkat, bagan, hubungan antarkategori dan penarikan kesimpulan dengan memanfaatkan pivot table di microsoft excel.

\section{HASIL DAN PEMBAHASAN}

Kampanye iklan 1 adalah basis yang digunakan untuk melakukan kampanye iklan berikutnya. Pada kampanye pertama lokasi geografis konsumen diatur berada di Indonesia. Di kampanye iklan pertama ini ukuran pemirsanya masih luas yaitu 23.000.000 orang. Dari jumlah tersebut, mengacu pada anggaran yang digunakan diperkirakan akan ada 1.200-3.400 orang per hari yang akan melihat kampanye iklan ini dan menghasilkan 28-81 klik tautan iklan.Hasil yang diperoleh dari kampanye iklan pertama adalah sebagai berikut:

Tabel 1 Hasil Kampanye Iklan 1

\begin{tabular}{|c|c|c|c|}
\hline Reporting Starts & (All) & & \\
\hline Reporting Ends & (All) & & \\
\hline Row Labels & $\begin{array}{ll}\text { Sum } \\
\text { Reach }\end{array}$ & $\begin{array}{l}\text { Sum } \\
\text { Impressions }\end{array}$ & $\begin{array}{l}\text { Sum of Amount Spent } \\
\text { (IDR) }\end{array}$ \\
\hline Aceh & 2438 & 3009 & 29150 \\
\hline Bali & 3168 & 3692 & 56312.5 \\
\hline Bangka-Belitung Islands & 1252 & 1470 & 9805 \\
\hline Banten & 3379 & 3378 & 34582.5 \\
\hline Bengkulu & 105 & 258 & 4505 \\
\hline Central Java & 1108 & 1151 & 21862.5 \\
\hline Central Kalimantan & 62 & 62 & 0 \\
\hline Central Sulawesi & 114 & 259 & 0 \\
\hline East Java & 3838 & 5058 & 80162.5 \\
\hline East Kalimantan & 111 & 219 & 27427.5 \\
\hline East Nusa Tenggara & 115 & 222 & 0 \\
\hline Gorontalo & 1190 & 1281 & 21332.5 \\
\hline Jakarta & 19395 & 23767 & 265000 \\
\hline Jambi & 2554 & 3090 & 27162.5 \\
\hline Lampung & 841 & 986 & 18550 \\
\hline Maluku & 627 & 803 & 11792.5 \\
\hline North Kalimantan & 669 & 769 & 16695 \\
\hline North Maluku & 306 & 430 & 4637.5 \\
\hline North Sulawesi & 72 & 130 & 4770 \\
\hline Papua & 343 & 356 & 4372.5 \\
\hline Riau & 1427 & 1658 & 18550 \\
\hline South East Sulawesi & 1511 & 1730 & 19345 \\
\hline South Kalimantan & 37 & 65 & 4505 \\
\hline South Sulawesi & 591 & 722 & 6757.5 \\
\hline South Sumatra & 91 & 176 & 0 \\
\hline Special Region & 3695 & 3949 & 56445 \\
\hline
\end{tabular}


Jurnal Manajemen Strategi dan Aplikasi Bisnis, 3(1), 51 - 64

Tinton Ramadhan \& Ika Suhartanti Darmo. Data pemasaran digitial, lokasi geografis

Yogyakarta

West Java

West Kalimantan

22339

24534

290307.5

West Nusa Tenggara

2764

3253

30210

$2526 \quad 2636$

31005

West Papua

494

616

8215

West Sulawesi

1232

1265

8215

West Sumatra

4383

4901

42135

Grand Total

82777

95895

1153810

Sumber: Olahan Peneliti, 2019.

Di kampanye pertama ini, iklan berhasil menjangkau 82.777 akun yang berada di 32 wilayah berbeda di Indonesia. Iklan ini dilihat 95.895 kali oleh seluruh akun tersebut, sehingga satu akun rata-rata melihat iklan pada kampanye pertama ini sebanyak 1,15 kali. Total dana yang dihabiskan selama kampanye berlangsung adalah Rp 1.153.810,-. Dari kampanye ini kemudian berhasil mendatangkan omset sebagai berikut:

Tabel 2 Hasil Penjualan Kampanye Iklan 1

\begin{tabular}{|l|l|l|l|l|}
\hline Sales Date & Sales Region & $\begin{array}{l}\text { Sales Specific } \\
\text { Region }\end{array}$ & $\begin{array}{l}\text { Order } \\
\text { Value }\end{array}$ & Order \\
\hline 22-Dec-18 & Lampung & Way Kanan & 296.000 & messenger \\
\hline 21-Dec-18 & West Java & Bekasi & 153.000 & messenger \\
\hline 13-Dec-18 & West Java & Bekasi & 153.000 & messenger \\
\hline 13-Dec-18 & West Java & Depok & 153.000 & messenger \\
\hline 5-Dec-18 & Jakarta & Jakarta Timur & 153.000 & messenger \\
\hline 27-Dec-18 & Jakarta & Jakarta Barat & 153.000 & website cart \\
\hline 26-Dec-18 & West Java & Sukabumi & 153.000 & website cart \\
\hline 26-Dec-18 & Banten & Tangerang Selatan & 153.000 & website cart \\
\hline
\end{tabular}

Sumber: Olahan Peneliti, 2019

Wilayah spesifik didapatkan dari alamat pengiriman produk yang diberikan oleh konsumen. Jika dianalisis lebih lanjut maka dari data tersebut bisa didapatkan informasi sebagai berikut:

Tabel 3 Hasil Penjualan Kampanye Iklan 1 Per-Wilayah.

\begin{tabular}{ll}
\hline Penjualan & Sum of Order Value \\
\hline Row Labels & $\mathbf{1 5 3 . 0 0 0}$ \\
\hline Banten & 153000 \\
\hline Tangerang Selatan & $\mathbf{3 0 6 . 0 0 0}$ \\
Jakarta & 153000 \\
\hline Jakarta Barat & 153000 \\
Jakarta Timur & $\mathbf{2 9 6 . 0 0 0}$ \\
Lampung & 296000 \\
\hline Way Kanan & $\mathbf{6 1 2 . 0 0 0}$ \\
West Java & 306000 \\
Bekasi & 153000 \\
Depok & 153000 \\
Sukabumi & $\mathbf{1 . 3 6 7 . 0 0 0}$ \\
\hline Grand Total &
\end{tabular}


Dari data-data diatas kemudian dapat disimpulkan sebagai berikut:

Nilai Persentase Biaya Iklan/ Hasil Penjualan: 84\%

Tabel 4.4 Perbandingan Biaya Iklan dan Hasil Penjualan (1).

\begin{tabular}{llll}
\hline Bulan & Biaya Iklan & Hasil Penjualan & Persentase Biaya/ Hasil Penjualan \\
Des & $1.153 .810,00$ & $1.367 .000,00$ & $84 \%$ \\
\hline
\end{tabular}

Sumber: Olahan Peneliti, 2019.

Penjualan terbanyak berasal dari West Java (Jawa Barat) dengan total penjualan 612.000 atau sekitar 4 (empat) produk. Dari hasil ini dan juga penelitian sebelumnya dari Lyer et al (2005:461) dan Birgisdóttir (2018:41) yang menyatakan bahwa menggunakan periklanan yang tertarget dapat berkontribusi pada penurunan anggaran pemasaran yang tidak perlu. Hal-hal tersebut yang menjadi alasan untuk menggunakan periklanan tertarget, sebagai bagian dari penelitian ini. Pada eksperimen pertama akan diuji apakah terjadi penurunan persentase biaya/ hasil penjualan jika kampanye iklan difokuskan pada lokasi geografis penyumbang penjualan terbanyak, yaitu di Jawa Barat.

\section{Kampanye Iklan 2 (Eksperimen 2)}

Pada kampanye iklan kedua variabel bebas berupa lokasi geografis disesuaikan, dari seluruh Indonesia menjadi hanya khusus diiklankan di pemirsa yang berada di wilayah Jawa Barat. Di kampanye iklan kedua ini ukuran pemirsanya menurun ke 5.300.000 orang. Dari jumlah tersebut, dari anggaran yang digunakan, sayangnya tidak diketahui jumlah orang yang diperkirakan akan melihat dan melakukan klik pada tautan iklan seperti pada kampanye pertama.Hasil yang diperoleh dari kampanye iklan kedua adalah sebagai berikut:

Tabel 4. Hasil Kampanye Iklan 2

\begin{tabular}{ll} 
Reporting & \\
Starts & (All) \\
Reporting & \\
Ends & (All) \\
\hline
\end{tabular}

\begin{tabular}{|lllll|} 
Row Labels & $\begin{array}{l}\text { Sum } \\
\text { Reach }\end{array}$ & $\begin{array}{l}\text { of } \\
\text { Impressions }\end{array}$ & $\begin{array}{l}\text { of } \\
\text { Sum of Amount Spent } \\
\text { (IDR) }\end{array}$ \\
\hline West Java & 126.712 & 133.962 & 1.152 .492 .5 \\
\hline Grand Total & $\mathbf{1 2 6 . 7 1 2}$ & $\mathbf{1 3 3 . 9 6 2}$ & $\mathbf{1 . 1 5 2 . 4 9 2 . 5}$ \\
\hline
\end{tabular}

Sumber: Olahan Peneliti, 2019

Di kampanye kedua ini, iklan berhasil menjangkau 126.712 akun yang berada di wilayah Jawa Barat, lebih banyak dari kampanye iklan sebelumnya yang hanya menjangkau 82.777 akun. Iklan ini dilihat 133.962 kali, lebih banyak dari kampanye sebelumnya yang hanya mencapai 95.895 kali. Total dana yang dihabiskan selama kampanye berlangsung adalah Rp 1.152.492,-. Dari kampanye ini kemudian berhasil mendatangkan omset sebagai berikut: 
Jurnal Manajemen Strategi dan Aplikasi Bisnis, 3(1), 51 - 64

Tinton Ramadhan \& Ika Suhartanti Darmo. Data pemasaran digitial, lokasi geografis

Tabel 5 Hasil Penjualan dari Kampanye Iklan 2

\begin{tabular}{lllll}
\hline Sales Date & Sales Region & Sales Specific Region & Order Value & Order \\
\hline 30-Jan-19 & West Java & Bekasi & 153000.00 & messenger \\
30-Jan-19 & West Java & Bekasi & 153000.00 & messenger \\
30-Jan-19 & West Java & Bekasi & 296000.00 & messenger \\
30-Jan-19 & West Java & Depok & 153000.00 & website cart \\
30-Jan-19 & West Java & Bogor & 153000.00 & website cart \\
30-Jan-19 & West Java & Bekasi & 153000.00 & website cart \\
30-Jan-19 & West Java & Depok & 153000.00 & messenger \\
30-Jan-19 & West Java & Bekasi & 153000.00 & messenger \\
29-Jan-19 & West Java & Bandung & 153000.00 & messenger \\
29-Jan-19 & West Java & Bekasi & 153000.00 & messenger \\
25-Jan-19 & West Java & Bekasi & 153000.00 & website cart \\
24-Jan-19 & West Java & Depok & 153000.00 & messenger \\
17-Jan-19 & West Java & Karawang & 153000.00 & messenger \\
16-Jan-19 & West Java & Bekasi & 153000.00 & website cart \\
3-Jan-19 & West Java & Karawang & 153000.00 & messenger \\
\hline
\end{tabular}

Sumber: Olahan Peneliti

Wilayah spesifik didapatkan dari alamat pengiriman produk yang diberikan oleh konsumen. Jika dianalisis lebih lanjut maka dari data tersebut bisa didapatkan informasi sebagai berikut:

Tabel 7 Penjualan Kampanye Iklan 2 di Wilayah Jawa Barat

$\begin{array}{ll}\text { Sales Date } & \text { (All) } \\ \text { Order } & \text { (All) }\end{array}$

\begin{tabular}{|cl|} 
Row Labels & $\begin{array}{l}\text { Sum of } \\
\text { Value }\end{array}$ \\
\hline West Java & $\mathbf{2 4 3 8 0 0 0}$ \\
\hline Bandung & 153000 \\
Bekasi & 1.367 .000 \\
Bogor & 153000 \\
Depok & 459000 \\
Karawang & 306000 \\
\hline Grand Total & $\mathbf{2 . 4 3 8 . 0 0 0}$ \\
\hline
\end{tabular}

Sumber: Olahan Peneliti, 2019

Dari data-data diatas kemudian dapat disimpulkan sebagai berikut:

Nilai Persentase Biaya Iklan/ Hasil Penjualan: 47\%

Tabel 8 Perbandingan Biaya Iklan dan Hasil Penjualan (2)

\begin{tabular}{|l|l|l|l|}
\hline Bulan & Biaya Iklan & Hasil Penjualan & Persentase Biaya/ Hasil Penjualan \\
\hline Des & $1,152,492.50$ & $2,438,000.00$ & $47 \%$ \\
\hline
\end{tabular}

Sumber: Olahan Peneliti, 2019 
1. Hasil ini menunjukkan bahwa saat lokasi geografis difokuskan pada wilayah yang menghasilkan penjualan terbanyak, nilai persentase biaya/ hasil penjualan akan turun, yaitu dari $84 \%$ ke $47 \%$.

2. Penjualan terbanyak berasal dari Bekasi dengan total penjualan 1.367 .000 atau sekitar 9 (sembilan) produk.

\section{Kampanye Iklan 3 (Eksperimen 3)}

Pada kampanye iklan ketiga variabel bebas berupa lokasi geografis disesuaikan, dari seluruh Jawa Barat menjadi hanya khusus diiklankan di pemirsa yang berada di wilayah Bekasi sebagai wilayah yang menjadi sumber asal konsumen terbanyak. Di kampanye iklan kedua ini ukuran pemirsanya menurun ke 2.000 .000 orang. Dari jumlah tersebut, dari anggaran yang digunakan diperkirakan akan menjangkau 1.000-2.900 orang per hari dan menghasilkan klik pada tautan sebanyak 26-75 kali.Hasil yang diperoleh dari kampanye iklan ketiga adalah sebagai berikut:

Tabel 9 Hasil Kampanye Iklan 3

\begin{tabular}{|c|c|c|c|}
\hline $\begin{array}{l}\text { Reporting } \\
\text { Starts }\end{array}$ & (All) & & \\
\hline $\begin{array}{l}\text { Reporting } \\
\text { Ends }\end{array}$ & (All) & & \\
\hline Row Labels & $\begin{array}{l}\text { Sum of } \\
\text { Reach }\end{array}$ & $\begin{array}{ll}\text { Sum } & \text { of } \\
\text { Impressions } & \end{array}$ & $\begin{array}{l}\text { Sum of Amount Spent } \\
\text { (IDR) }\end{array}$ \\
\hline Bekasi & 84823 & 89519 & 1154185 \\
\hline Grand Total & 84.823 & 89.519 & 1.154 .185 \\
\hline
\end{tabular}

Sumber: Olahan Peneliti, 2019

Di kampanye kedua ini, iklan berhasil menjangkau 84.823 akun yang berada di wilayah Bekasi. Iklan ini dilihat 89.519 kali, jumlah yang lebih sedikit dibandingkan pada kampanye iklan kedua. Total dana yang dihabiskan selama kampanye berlangsung adalah Rp 1.154.185,-. Dari kampanye ini kemudian berhasil mendatangkan omset sebagai berikut:

Tabel 10 Hasil Penjualan Kampanye Iklan 3

\begin{tabular}{|c|c|c|c|c|}
\hline Sales Date & Sales Region & $\begin{array}{l}\text { Sales Specific } \\
\text { Region }\end{array}$ & Order Value & Order \\
\hline 26-Feb-19 & West Java & Bekasi & 153000.00 & messenger \\
\hline 26-Feb-19 & West Java & Bekasi & 153000.00 & messenger \\
\hline 25-Feb-19 & West Java & Bekasi & 153000.00 & website cart \\
\hline 25-Feb-19 & West Java & Bekasi & 888000.00 & website cart \\
\hline 25-Feb-19 & West Java & Bekasi & 153000.00 & website cart \\
\hline 25-Feb-19 & West Java & Bekasi & 296000.00 & messenger \\
\hline 25-Feb-19 & West Java & Bekasi & 153000.00 & messenger \\
\hline 25-Feb-19 & West Java & Bekasi & 153000.00 & messenger \\
\hline 17-Feb-19 & West Java & Bekasi & 153000.00 & messenger \\
\hline 15-Feb-19 & West Java & Bekasi & 296000.00 & messenger \\
\hline 15-Feb-19 & West Java & Bekasi & 153000.00 & website cart \\
\hline 10-Feb-19 & West Java & Bekasi & 153000.00 & messenger \\
\hline 8-Feb-19 & West Java & Bekasi & 153000.00 & messenger \\
\hline 5-Feb-19 & West Java & Bekasi & 153000.00 & website cart \\
\hline
\end{tabular}


Jurnal Manajemen Strategi dan Aplikasi Bisnis, 3(1), 51 - 64

Tinton Ramadhan \& Ika Suhartanti Darmo. Data pemasaran digitial, lokasi geografis

\begin{tabular}{lllll}
\hline 5-Feb-19 & West Java & Bekasi & 296000.00 & website cart \\
4-Feb-19 & West Java & Bekasi & 153000.00 & messenger \\
3-Feb-19 & West Java & Bekasi & 153000.00 & messenger \\
\hline
\end{tabular}

Wilayah spesifik didapatkan dari alamat pengiriman produk yang diberikan oleh konsumen. Jika dianalisis lebih lanjut maka dari data tersebut bisa didapatkan informasi sebagai berikut:

Tabel 11 Hasil Penjualan Kampanye Iklan 3 di Wilayah Bekasi

\begin{tabular}{ll}
\hline Sales Date & (All) \\
Order & (All)
\end{tabular}

\begin{tabular}{|cl} 
Row Labels & Sum of Order Value \\
\hline West Java & $\mathbf{3 7 6 5 0 0 0}$ \\
\hline Bekasi & 3765000 \\
\hline Grand Total & $\mathbf{3 . 7 6 5 . 0 0 0}$ \\
\hline
\end{tabular}

Sumber: Olahan Peneliti, 2019.

Dari data-data diatas kemudian dapat disimpulkan sebagai berikut:

Nilai Persentase Biaya Iklan/ Hasil Penjualan: 31\%

Tabel 12 Perbandingan Biaya Iklan dan Hasil Penjualan (3)

\begin{tabular}{|c|c|c|c|c|}
\hline Bulan & Biaya Iklan & Hasil Penjualan & $\begin{array}{l}\text { Persentase } \\
\text { Penjualan }\end{array}$ & Biaya/Hasil \\
\hline Des & $1,154,185.00$ & $3,765,000.00$ & $31 \%$ & \\
\hline
\end{tabular}

Sumber: Olahan Peneliti, 2019

Hasil ini sekaligus juga memperlihatkan hasil saat lokasi geografis difokuskan pada wilayah yang menghasilkan penjualan terbanyak, nilai persentase biaya/ hasil penjualan akan turun, yaitu dari $47 \%$ ke $31 \%$. Penjualan kampanye periode terakhir menghasilkan 17 transaksi dengan total nilai Rp 3.765.000 atau yang terbesar dari 2 (dua) kampanye iklan sebelumnya.

\section{Diskusi}

Jika dipadatkan maka ketiga kampanye diatas menghasilkan data sebagai berikut:

Tabel 4.13 Ringkasan Hasil Kampanye Iklan 1-3

\begin{tabular}{|c|c|c|c|c|c|c|}
\hline Bulan & $\begin{array}{l}\text { Biaya } \\
\text { (a) }\end{array}$ & $\begin{array}{l}\text { Penjualan } \\
\text { Produk (b) }\end{array}$ & (a)/ (b) & $\begin{array}{l}\text { Periode } \\
\text { Iklan }\end{array}$ & $\begin{array}{l}\text { Lokasi } \\
\text { Geografis }\end{array}$ & Transaksi \\
\hline Des & $1,153,810.00$ & $1,367,000.00$ & $84 \%$ & 1 Bulan & Indonesia & 8 \\
\hline Jan & $1,152,492.50$ & $2,438,000.00$ & $47 \%$ & 1 Bulan & West Java & 15 \\
\hline Feb & $1,154,185.00$ & $3,765,000.00$ & $31 \%$ & 1 Bulan & Bekasi & 17 \\
\hline Total & $3,460,487.50$ & $7,570,000.00$ & $46 \%$ & 3 Bulan & Average & 40 \\
\hline
\end{tabular}

Sumber: Olahan Peneliti, 2019

Dari tabel diatas bisa dilihat ada perkembangan penjualan produk dan presentase beban iklan atas penjualan yang terus menurun. Dari Rp 1.367.0000 dalam 8 transaksi di bulan pertama saat pengaturan iklan dibuat untuk ditayangkan ke seluruh Indonesia. Angka penjualan kemudian naik menjadi Rp 2.438.000 dari 15 transaksi yang terjadi saat pengaturan iklan hanya ditayangkan di wilayah Jawa Barat yang merupakan penghasil penjualan terbanyak di periode sebelumnya. Angka 
penjualan kembali naik ke Rp. 3.765.000 saat wilayah tayangan dipersempit kembali di Bekasi yang merupakan penyumbang terbanyak penjualan di periode sebelumnya. Hasil tersebut menunjukkan bahwa lokasi geografis yang tepat dalam menayangkan iklan dapat meningkatkan kinerja kampanye iklan. Untuk bisa mendapatkan lokasi geografis yang tepat, bisa dilakukan dengan menyasar wilayah yang lebih luas terlebih dahulu untuk kemudian dari data yang diperoleh dari kampanye iklan dan penjualan bisa ditentukan wilayah yang punya potensi lebih baik untuk dijadikan sasaran tayangan iklan.

\section{KESIMPULAN}

\section{Kesimpulan}

Terjadi peningkatan penjualan produk saat dilakukan penyesuaian lokasi geografis iklan pada wilayah yang menghasilkan penjualan terbanyak di kampanye sebelumnya. Peningkatannya adalah sebagai berikut dari Rp 1.367.0000 yang berasal dari 8 transaksi di bulan pertama saat iklan ditayangkan ke seluruh Indonesia. Angka penjualan kemudian naik menjadi Rp 2.438.000 dari 15 transaksi yang terjadi saat pengaturan iklan hanya ditayangkan di wilayah Jawa Barat yang merupakan penghasil penjualan terbanyak di periode sebelumnya. Angka penjualan kembali naik ke Rp. 3.765.000 saat wilayah tayangan dipersempit kembali di Bekasi yang merupakan penyumbang terbanyak penjualan di periode sebelumnya.

\section{Implikasi Praktis / Teoritis}

Data pemasaran digital dapat dimanfaatkan untuk menentukan lokasi geografis terbaik untuk menayangkan iklan produk. Dapat dilihat dari hasil penempatan iklan produk secara umum di wilayah Indonesia menghasilkan persentase beban iklan terhadap total pendapatan sebesar $84 \%$. Persentase ini menurun menjadi 47\% saat kampanye iklan difokuskan di wilayah Jawa Barat, yang merupakan wilayah terbaik dari segi penjualan di periode sebelumnya. Persentase ini kemudian menurun lagi menjadi 31\% saat kampanye iklan di fokuskan di wilayah Bekasi, yang menyumbang penjualan terbanyak di wilayah Jawa Barat pada periode sebelumnya. Hasil-hasil tersebut menunjukkan bahwa lokasi geografis yang tepat dalam menayangkan iklan dapat meningkatkan kinerja kampanye iklan. Untuk bisa mendapatkan lokasi geografis yang tepat, bisa dilakukan dengan menyasar wilayah yang lebih luas untuk kemudian dari data yang diperoleh dari kampanye iklan dan penjualan bisa ditentukan wilayah dengan potensi lebih baik untuk dijadikan sasaran tayangan iklan.

\section{Keterbatasan / Saran}

Dalam penelitian selanjutnya dapat menguji sampai sejauh mana sebuah daerah dapat dieksploitasi peluang pasarnya sampai mencapai titik jenuh dan mengalami penurunan permintaaan.

\section{REFERENSI}

Arifah, P., N. dan Mustikarini, C, N. (2016). Paid Promote Sebagai Media Promosi Produk Delicy Dalam Meningkatkan Konsumen Potensial. PERFORMA: Jurnal Manajemen dan Start-Up Bisnis Volume 1, Nomor 3, Agustus $2016 . \quad$ [Online]. Available:https:// journal.uc.ac.id/index.php/performa/ article/ download/173/159. Diakses 30 Oktober 2018

Birgisdóttir, I, H. (2018). How can Car Dealerships use Targeted Advertising to Reach Customers More Efficiently? The Case of the Car Dealership Askja. [Online]. Available:https:// skemman.is/ handle/1946/ 31223. Diakses 30 Oktober 2018.

Ekawati, N, W. (2012). Jejaring Sosial/ Facebook Sebagai Media E-Pengecer (Studi Kasus Mahasiswa Di Kota Denpasar). [Online]: Available: http:// eprints.mercubuanayogya.ac.id/ 4121/3/ BAB\%20II.pdf. Diakses 30 Oktober 2018 
Jurnal Manajemen Strategi dan Aplikasi Bisnis, 3(1), 51 - 64

Tinton Ramadhan \& Ika Suhartanti Darmo. Data pemasaran digitial, lokasi geografis

Giroux, M., Pons, F., \& Maltese, L. (2017). The role of perceived brand personality in promotion effectiveness and brand equity development of professional sports teams. International Journal of Sports Marketing and Sponsorship. 18(2), 180-195

Gordon, B. R., Jerath, K., Katona, Z, Narayanan, S., Shin, J., \& Wilbur, K. C. (2019). Inefficiencies in Digital Advertising Markets. arXiv preprint arXiv:1912.09012.

Jushermi. (2013). Analisis Segmentasi Gaya Hidup Pada Mahasiswa Jurusan Manajemen S1 Fakultas Ekonomi Universitas Riau. JURNAL EKONOMI Volume 21, Nomor 1 Maret 2013. [Online]. Available: $\quad$ https:// media.neliti.com/media/ publications/ 8697-ID-analisis-segmentasi-gayahidup-pada-mahasiswa-jurusan-manajemen-s1-fakultas-ekon.pdf. Diakses 30 Oktober 2018.

Luo, C. (2017). Demographic-Related Purchase Behaviours of Consumers: The Evolving Tension between Exploration and Exploitation in Frequently Purchased Consumer Goods Markets (Doctoral dissertation, The University of Manchester (United Kingdom)).

Lyer, G., Soberman, D., \& Villas-Boas, J. M. (2005). The Targeting of Advertising. Marketing Science, 24(3), 461-476. https:// doi.org/ 10.1287/ mksc.1050.0117.

Maulana, R, F. (2017). Bagaimana Potensi Digital Marketing Indonesia di Tahun 2017? [Online]. Available: https:/ / id.techinasia.com/ potensi-digital-marketing-indonesia-di-tahun-2017. Diakses 30 Oktober 2018

Nguyen, N., Greenland, S., Lobo, A., \& Nguyen, H. V. (2019). Demographics of sustainable technology consumption in an emerging market: The significance of education to energy efficient appliance adoption. Social Responsibility Journal. 15(6), 803-818.

Semerádová, T., \& Weinlich, P. (2019). Computer Estimation of Customer Similarity With Facebook Lookalikes: Advantages and Disadvantages of Hyper-Targeting. IEEE Access, 7, 153365153377.

Sugiharto, S dan Cahyadi, D.H. (2014). Pengaruh Private Brand Strategy Terhadap Brand Loyalty Pada Air Mineral 600ml Merek Alfa Di Alfamart Siwalankerto Surabaya.Jurnal Strategi Pemasaran Vol 2,No 1(2014). [Online]. Available: https:/ / media.neliti.com/ media/ publications/ 132935-ID-pengaruh-private-brand-strategyterhadap.pdf. Diakses 30 Oktober 2018

Van den Broeck, E., Poels, K., \& Walrave, M. (2020). How do users evaluate personalized Facebook advertising? An analysis of consumer-and advertiser controlled factors. Qualitative Market Research: An International Journal.

Zaenudin, Ahmad. (2017). Siasat Cerdik Facebook Lewat Pembaruan Algoritma. [Online]. Available: https:// tirto.id/ siasat-cerdik-facebook-lewat-pembaruan-algoritma-cixF. Diakses 30 Oktober 2018.

\section{PROFIL PENULIS}

Tinton Ramadhan adalah dosen Prodi Manajemen Fakultas Bisnis Institut Teknologi dan Bisnis Kalbis dengan pengalaman mengajar di bidang kewirausahaan seperti perencanaan bisnis, kewirausahaan 1-4 dan manajemen inovasi ditingkat sarjana. Penulis memiliki ketertarikan pada penelitian kewirausahaan, usaha rintisan dan pemasaran digital. Tinton Ramadhan adalah penulis koresponden dapat dihubungi di: tinton.ramadhan@kalbis.ac.id. 
Jurnal Manajemen Strategi dan Aplikasi Bisnis, 3(1), 51-64

Tinton Ramadhan \& Ika Suhartanti Darmo. Data pemasaran digitial, lokasi geografis

This page intention to blank... 